\title{
CONSONANT GEMINATES IN SIMALUNGUN LANGUAGE
}

\author{
Luh Anik Mayani* \\ Badan Pengembangan dan Pembinaan Bahasa \\ annie_mayani@yahoo.com
}

\begin{abstract}
Abstrak
Penelitian ini bertujuan untuk mendeskripsikan proses morfofonemik yang dapat menghasilkan geminat dan jenis-jenis geminat dalam bahasa Simalungun. Jenis geminat dibedakan berdasarkan proses morfofonemiknya serta berdasarkan kesejatian geminat, yaitu tipe geminat sejati dan taksejati. Data dalam penelitian ini dikumpulkan melalui penelitian lapangan di Pematang Raya, Kecamatan Raya, Kabupaten Simalungun, Provinsi Sumatra Utara. Berdasarkan analisis dapat disimpulkan bahwa geminat dalam bahasa Simalungun selalu berada di tengah kata. Geminat yang ditemukan adalah [pp], [tt], [kk], [ss], [11], [gg], [nn], dan [mm]. Berdasarkan proses morfofonemik, geminat dalam bahasa ini dapat dibagi menjadi empat, yaitu geminat yang merupakan hasil dari proses (1) asimilasi nasal mengikuti bunyi hambat homorganik yang ada di belakangnya, (2) velarisasi dan asimilasi, (3) asimilasi bunyi berbeda dalam konsonan rangkap, dan (4) geminat nasal. Berdasarkan kesejatian geminat, Simalungun memiliki geminat sejati dan taksejati. Geminat sejati bersifat leksikal; geminat taksejati dihasilkan melalui proses afiksasi dan klitisasi. Geminat sejati yang ditemukan adalah [pp], [tt], [ss], [kk], [gg] and [mm], sedangkan yang taksejati adalah [ss], [kk], [1l] and [nn].
\end{abstract}

Kata kunci: geminat konsonan, Simalungun, proses morfofonemik

\begin{abstract}
This study aims to describe morphophonemic processes which result in consonant geminates as well as to classify types of consonant geminates in Simalungun language. Types of geminates in this study are analyzed from the morphophonemic processes resulted in consonant geminates and from the true or fake types of geminates. The data analyzed in this paper is collected during a short fieldwork in Pematang Raya, Kecamatan Raya (Raya district), Simalungun regency, Sumatra Utara Province. From the analysis, it can be concluded that consonant geminates in Simalungun language always occur word-medially. Consonant geminates found in this language are [pp], [tt], $[\mathrm{kk}],[\mathrm{ss}],[11],[\mathrm{gg}],[\mathrm{nn}]$ and $[\mathrm{mm}]$. Based on the morphophonemic processes, geminates in Simalungun language can be divided into four types: (1) consonant geminates resulted from assimilation of a nasal to a following homorganic stop, (2) consonant geminates resulted from velarization and assimilation, (3) assimilation of heterorganic consonant clusters and (4) nasal geminates. Regarding true and fake type of geminates, true geminates in Simalungun are found morpheme-internally or lexicalized; fake geminates are resulted from affixation and clitization. True geminates in Simalungun are [pp], [tt], [ss], [kk], [gg] and [mm], while fake geminates found in this language are [ss], [kk], [11] and [nn].
\end{abstract}

Keywords: consonant geminates, Simalungun, morphophonemic process 


\section{INTRODUCTION}

Batak Simalungun (bts) is a Malayo-Polynesian language spoken by around 1,2 million people in Sumatra Utara Province, Simalungun, Serdang Bedagai, Deli Serdang, Kota Pematang Siantar regencies and area northeast of Lake Toba, south of Medan. It is a developing language and it has Batak as well as Latin scripts (Lewis, et.al. 2016).

Some studies have been done on this language. Tarigan (1975), in his doctoral dissertation, divides Batak Simalungun into four dialects: Silimakuta, Raya, Topi Pasir (Horisan) and Jahe-Jahe (Pesisir Pantai Timur). Meanwhile, Siregar et.al. (2001:8) geographically divides dialects of Simalungun into three dialects: high(land), middle(land) and low(land) dialects. A short sketch on morphology and syntax of Batak Simalungun has been done by Damanik et.al. (1984) and the phonology of Simalungun language has been written by Siregar et.al. (2001). Other works on Simalungun are Zimbo (Cerita Rakyat Simalungun) 'Simalungun Folk Stories' by Sitanggang (1996) and Limbaga (Peribahasa Bahasa Simalungun) 'Simalungun Proverbs' written by Baharuddin et.al. (1997).

This paper describes some aspects which have not been extensively described by Tarigan (1975), Damanik et.al. (1984) or Siregar (2001). Two issues discussed in this paper are (1) the morphophonemic processes which result in consonant geminates in Simalungun and (2) types of consonant geminates found in Simalungun. Types of geminates in this study are analyzed from the morphophonemic processes resulted in consonant geminates and from the true or fake type of geminates.

The data analyzed in this paper is collected during a short fieldwork in Pematang Raya, Kecamatan Raya (Raya district), Simalungun regency, Sumatra Utara Province. Based on the dialect classification proposed by Tarigan (1975), the dialect of Batak Simalungun spoken in this area is Raya dialect. The speakers in this district prefer to call their language as well as their ethnic group simply as Simalungun, rather than Batak Simalungun. According to Prof. Amrin Saragih, a linguistics professor at the State University Medan, this preference is in accordance with the name given to the church, Gereja Kristen Protestan Simalungun (GKPS, the Protestant Church of Simalungun). In this name, Simalungun is used without mentioning Batak. Another reason stated by the informants is that the word batak itself is highly associated with Batak Toba. When one simply says Batak, people will directly associate this word to the Batak Toba ethnic group or language. Therefore, Simalungun people are more likely to call their ethnic as well as their language as Simalungun, not as Batak Simalungun. Regarding this fact, Batak Simalungun (bts) in this paper will be simply called Simalungun or Simalungun language.

In Pematang Raya, Simalungun language is used in everyday communication. It is taught at schools since the 1990s and it is used in religious as well as ritual activities in the village and churches. However, it should be also noted that nowadays young generation prefers to use Indonesian at schools and at homes. In addition to Indonesian, another language used in the area is Tapanuli language. Sociolinguistically, politeness in Simalungun language is marked by the use of personal pronouns. In order to show respect, Simalungun speakers will address the addressee by using the honorific form for the second person pronoun, ham '2SG.HON' or handian '2SG.HON', or by using the second person plural, nansiam '2PL'. Note that the nonhonorific form for the second person is ho ' $2 \mathrm{SG}$ '.

In addition to some studies listed above, Simalungun language has been docummented in the form of dictionary (i.e. Simalungun-Indonesian dictionary) published by Balai Bahasa Provinsi Sumatera Utara (2016) and Simalungun people have Bible which is in Simalungun 
language. There is a weekly newspaper called Suara Simalungun 'Simalungun Voice' which is written in Simalungun language and Mora Radio as well as Evarina TV broadcast local programs in Simalungun language.

The data was compiled by recording hundreds of lexicons and elicited data was collected by individual interviews. During the fieldwork, I intensively worked with three informants: Hanny Sinaga (18 years old), Fitria Sinaga (23 years old) and Hassanuddin Purba (59 years old). Recorded lexicon is used to list phoneme inventory in Simalungun; elicited data is mainly used to analyze consonant geminates and the morphophonemic processes in Simalungun. In addition to the data collected during the fieldwork, some data in this paper are quoted from the work of Damanik et.al. (1984) and from Siregar et.al. (2001).

\section{PREVIOUS STUDIES}

Damanik et.al. (1984) describe the morphology and syntax of Bahasa Batak Simalungun. Morphological aspects discussed in this book are word class classifications, reduplications, the forms, functions and meaning of affixes and a brief discussion on morphophonemic processes in Simalungun language.

Word classes classified by Damanik et.al. (1984) are nouns, verbs, adjectives, numeral and particles. Morphemes listed are prefixes $\{$ mar- $\},\{$ ma- $\},\{\operatorname{tar}-\},\{$ marsi- $\},\{$ mangka- $\},\{$ ni- $\}$, $\{\mathrm{i}-\},\{$ sa- $\},\{$ par- $\}$ and $\{$ pa- $\}$; infixes $\{-$ um- $\},\{-$ ul- $\}$ and $\{$-ur- $\}$; suffixes $\{-$ tu $\},\{-n i\},\{-i\}$, $\{$-hon/kon $\},\{-o n\}$ and $\{-$ an $\}$; circumfixes $\{$ pa--hon/kon $\},\{$ ha--an/on $\}$ and $\{$ marsi--an $\}$. This work, however, does not differentiate morphological units which function as affixes from clitics. The morphological units $\{$-hu $\}$ '1SG.POSS', \{-ta\} '1PL.POSS' and \{-mu\} '2SG.POSS' which potentially analyzed as clitics are categorized as suffixes. Moreover, nasal prefixes are analyzed as allomorphs of non-nasal prefixes, thus $\{$ ma- $\}$ and $\{$ pa- $\}$ respectively may change into $\{\mathrm{maN}-\}$ and $\{\mathrm{paN}-\}$.

The morphophonemic processes described by Damanik et.al. (1984) are the morphophonemics of $\{$ ma- $\},\{$ pa- $\},\{-h o n\},\{-h u\},\{-$ ta $\},\{-\mathrm{mu}\},\{-\mathrm{uN}-\},\{-\mathrm{an}\}$ and $\{-$ on $\}$. For example, the suffix $\{-\mathrm{hu}\}$ becomes $\{-\mathrm{ku}\}$ if it is preceded by bases ended with $/ \mathrm{h} /$, it becomes $\{-\mathrm{kku}\}$ if it attached to a word ended by a vowel and maintains its form as $\{-\mathrm{hu}\}$ elsewhere. Further, geminates resulted from morphophononemic processes have not been analyzed.

Syntactic description includes discussion on phrases (i.e. nominal phrases, verbal phrases, adjective phrases, numeral phrases, particle phrases, endocentric phrases and exocentric phrases. The discussion on clauses includes nominal clauses, adjective clauses, particle clauses, restrictive clauses and non-restrictive clauses. The description on syntax includes basic structures and extended sentence structures.

Siregar et.al. (2001) report that Simalungun has sixteen phonemes: /p/, /b/, /t/, /d/, /k/, $/ \mathrm{g} /, / \mathrm{d} 3 /, / \mathrm{s} /, / \mathrm{m} /, / \mathrm{n} /, / 1 /, / \mathrm{r} /, / \mathrm{h} /, / \mathrm{y} /, / \mathrm{w} /$ and $/ \mathrm{j} /$. In the following table, the phonemes are presented by standard IPA symbols, the voiced and voiceless phonemes appear side by side, voiceless ones on the left and voiced ones on the right. The description of place and manner of articulation of the Simalungun phonemes follow Siregar et.al. (2001:44). 
Table 1: Consonant phonemes in Simalungun

\begin{tabular}{|c|c|c|c|c|c|c|c|c|}
\hline & \multicolumn{2}{|c|}{ Bilabial } & \multicolumn{2}{|c|}{ Apico-alveolar } & Palatal & \multicolumn{2}{|c|}{$\begin{array}{c}\text { Dorso- } \\
\text { velar }\end{array}$} & Glottal \\
\hline Plosive & $\bar{p}$ & $\bar{b}$ & $\mathrm{t}$ & $\bar{d}$ & & $\overline{\mathrm{k}}$ & $\overline{\mathrm{g}}$ & \\
\hline Affricate & & & & & d3 & & & \\
\hline Fricative & & & $\mathrm{s}$ & & & & & $\mathrm{h}$ \\
\hline Nasal & & $\mathrm{m}$ & & $\mathrm{n}$ & & & y & \\
\hline Trill & & & & $\mathrm{r}$ & & & & \\
\hline Lateral & & & & 1 & & & & \\
\hline Approximant & & $\mathrm{w}$ & & & $\mathrm{j}$ & & & \\
\hline
\end{tabular}

In addition to sixteen consonant phonemes, Simalungun has five vowels, i.e. /i/, /u/, / / /, /o/ and /a/ as well as four diphthongs, i.e. /ei/, /ou/, /ui/ and /ai/. The description of the Simalungun vowel phonemes follows Siregar et.al. (2001:30) is presented in Table 2.

Table 2: Vowel phonemes in Simalungun

\begin{tabular}{|lccc|}
\hline & Front & Central & Back \\
\hline & Unrounded & Unrounded & Rounded \\
High & $\mathrm{i}$ & & $\mathrm{u}$ \\
Mid & & & \\
Low & $\varepsilon$ & $\mathrm{a}$ & $\mathrm{o}$ \\
\hline
\end{tabular}

Regarding geminates, Siregar et.al. (2001:105) mention that there are three consonant geminates in Simalungun which are orthographically written as $\langle\mathrm{mp}\rangle,\langle\mathrm{nt}\rangle$ and $\langle\mathrm{ngk}\rangle$. They propose that those geminates should be written phonemically as $/ \mathrm{pp} /, / \mathrm{tt} /$ and $/ \mathrm{kk} /$ or following the new orthographic system as $\langle\mathrm{pp}\rangle,\langle\mathrm{nt}\rangle$ and $\langle\mathrm{kk}\rangle$.

Related to syllable types, Simalungun has five possible types of syllables: V, VC, CV, CVV and CVC (Siregar et.al. 2001:93). It means that Simalungun has open and closed syllable structures. The distribution of the syllable types can be found in one to five syllabic words.

Blevins (2004:170-1) who studies geminates on 73 of the world languages states that there are at least seven identifiable pathways by which a single segment or a sequence of nonidentical segments can be transformed into a geminate consonant, resulting in the evolution of a consonant length contrast for a given language. General pathways in the evolution of consonantal length contrasts are:

1) Assimilation in consonant clusters

2) Assimilation between consonants and adjacent vowel/glides

3) Vowel syncope

4) Lengthening under stress (including expressive lengthening)

5) Boundary lengthening

6) Reinterpretation of a voicing contrast

7) Reanalysis of identical $\mathrm{C}+\mathrm{C}$ sequences

Dealing with Austronesian languages, Blust (2013:649) states that geminate consonants most commonly arise through one of four processes: (1) assimilation of a nasal to a following homorganic stops, (2) assimilation of heterorganic consonants in a cluster, (3) compensatory lengthening after schwa, followed by merger of schwa with some other vowel, (4) syncope between identical consonants for consonants that share a common place feature. 
Blust (2013:649) mentions that geminates resulted from assimilation of a nasal to a following homorganic stops can be illustrated by Batak Toba of northern Sumatra, which shows developments *mp > -pp-, *nt > -tt- and *yk > -kk as well as *ns > -ts-.

Moreover, he also mentions that heterorganic sequences of nasal + voiceless stop sometimes show geminating assimilation and sometimes do not: *kamkam > hakkam, but *tintiy $>$ tigtin. It is possible that preservation of the nasal in both halves of timtin is due to onomatopoetic retention. Sequences of nasal + voiced obstruent remained unchanged (Blust 2013:649).

Regarding the decision whether geminates should be treated as unit phonemes or as clusters, Blust (2013:651) says that speakers of Toba Batak are likely to percieve -pp-, -tt-, -kkas clusters. However, it is possible that cross-linguistically geminates which reflect consonant clusters preserve the syllable boundary, while those that reflect single stops are perceived as units.

Another work on geminates is done by Adelaar (2011:206) who reports that consonant gemination in various Malay dialects can also be the result of syllable reduction in avoidance of heterorganic consonant clusters. For example, Iban llapan 'eight' ( $<*$ delapan, Scott a956:VII). From eastern Indonesia, Hajek and Bowden (1999) report that initial geminates are frequently found in Taba, a little-known Austronesian language of the Maluku area of Central-Eastern Indonesia. For example, /'1lo/ 'blood' vs /'lo/ 'inside'. Taba allows 11 different geminates in word-initial position: /bb dd gg tt kk mm nn $\mathrm{y} y \mathrm{ll} \mathrm{hh} w w /$. Many examples of initial gemination in Taba result directly from a range of morphophonemic processes associated with prefixing, especially of proclitics.

Himmelmann (2001:71) found out that in Totoli and Boano, two identical consonant vowel (CV) syllables may be reduced to a geminate consonant plus vowel in Totoli sasaakan > ssaakan 'all', molili > molli 'yellow', $k u k u>k k u$ 'foot', etc.

Nastiti (2014:209) who did research on language contact between Buginese speech community and Samawa speech community in Sumbawa uses findings on geminates as the evidence of language contact between the two languages. The phonological characteristics of Buginese language can be traced from geminates found in Samawa language used in Labuhan

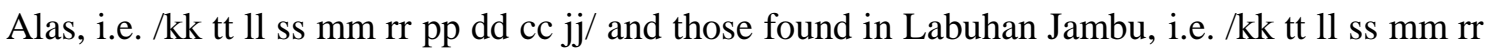
pp dd cc jj/.

\section{MORPHOPHONEMIC PROCESSES}

Morphophonemic processes analyzed by Damanik et.al. (1984) are those related with the following affixes: $\{$ ma- $\},\{$ pa- $\},\{-$ hon $\},\{-$ hu $\},\{-$ ta $\},\{-\mathrm{mu}\},\{-\mathrm{uN}-\},\{-\mathrm{an}\}$ and $\{-\mathrm{on}\}$. From the list, it can be seen that the morphological units \{-hu\} '1SG.POSS', \{-ta\} '1PL.EX.POSS' and $\{-\mathrm{mu}\}$ '2SG.POSS' are analyzed as suffixes, rather than as clitics. Further, Damanik et.al. (1984) analyze nasal prefixes as allomorphs of non-nasal prefixes, thus $\{\mathrm{ma}-\}$ and $\{\mathrm{pa}-\}$ respectively change into $\{\mathrm{maN}-\}$ and $\{\mathrm{paN}-\}$.

In this paper, however, I analyze the morphological units $\{$-hu $\}$ '1SG.POSS', \{-ta\} '1PL.EX.POSS' and \{-mu\} '2SG.POSS' as enclitics. From morphophonological point of view, affixes may trigger morphophonological alternations of the base to which they are attached. For example, a nasal prefix may undergo nasal assimilation or substitution. In contrast, morphophonological processes rarely occur at clitic boundaries. In Simalungun, the 
morphophonological process which does occur at a clitic boundary pertains to the enclitic $=h u$ '1SG.POSS', which results in consonant gemination, i.e. [kk] (see Section 5.3).

Further, clitization allows consonant sequences other than sonorant-obstruent sequences (see Section 4). The nasal-obstruent sequences found in Simalungun are $/ \mathrm{mp} /, / \mathrm{mb} /, / \mathrm{nt} /, / \mathrm{nd} /$, $/ \mathrm{nl} /, / \mathrm{nd} 3 /, / \mathrm{ns} /, / \mathrm{yk} /$ and $/ \mathrm{ng} /$. In contrast, consonant sequences which occur due to clitization are not homorganic. For example, the sequence $/ \mathrm{nm} /<\mathrm{ngm}>$ is found in the word inang=m $u$ 'mother=2SG.POSS' 'your mother' in which the last phoneme $/ \mathrm{l} /$ of the root inang 'mother' is followed by the phoneme $/ \mathrm{m} /$ of the enclitic $=m u$ '2SG.POSS'. Such sequences that remain phonologically unaltered may only occur between clitics and their (noun) hosts.

Some clitics may be derived from or related to independent or full forms. The first person singular enclitic $=h u$ is possibly derived from the first person singular pronoun $a h u$ and the first person plural exclusive $=t a$ is derived from hita '1PL.EX'. Based on those arguments, the morphological units $=h u$ '1SG.POSS', $=m u$ '2SG.POSS' and $=t a$ '1PL.EX.POSS' are analyzed as enclitics in this paper.

One has to be careful to conclude that $\{\mathrm{maN}-\}$ is derived from $\{$ ma- $\}$ because Simalungun also has the prefix $\{\mathrm{maR}-\}$ 'INTR' which can occur as $\{\mathrm{ma}-\}$, as in $\{\mathrm{maR}-\}+$ dabuh 'to fall' > madabuh 'to fall'. In this case, determining $\{\mathrm{ma}-\}$ as the underlying form of $\{\mathrm{maN}-\}$ would be debatable. In addition, from morphophonological point of view, sound deletion is more natural than sound addition. Thus, analyzing $\{\mathrm{ma}-\}$ is derived from $\{\mathrm{maN}-\}$ is more natural than saying that $\{\mathrm{maN}-\}$ is derived from $\{\mathrm{ma}-\}$. Moreover, in some Austronesian languages, it is common that nasal prefixes may undergo nasal assimilation or substitution and deletion. For example, the nasal prefix $\{$ noN- $\}$ in Tajio occurs as $\{$ no- $\}$ when it precedes bases begin with /1/, \{noN- $\}+$ leva 'to call' > noleva 'to call' (Mayani 2013). In Indonesian, the nasal prefix $\{$ meN- $\}$ derives as $\{$ me- $\}$ when it attaches to bases begin with $/ 1 /$ or $/ r /$, as in melawan 'to fight back' or merawat 'to take care'. Therefore, in this paper I analyze the nasal prefix $\{\mathrm{maN}-\}$ as the underlying form of the active voice marker in Simalungun language.

Morphophonemic processes discussed in this paper are only those which can result in consonant geminates, such as affixation and clitization. Consonant geminates resulted from affixation includes the use of the nasal prefix $\{\mathrm{maN}-\}$ and the suffix $\{$-hon $\}$ 'CAUS'. Another nasal prefix, i.e. $\{\mathrm{paN}-\}$ 'NOM', is not discussed here because it undergoes the same changes as the nasal prefix $\{\mathrm{maN}-\}$. Gemination resulted from clitization describes here is the use of the enclitic $=h u$ '1SG.POSS' and $=n i$ '3SG.POSS'.

Sections 3.1, 3.2 and 3.3 describe the general morphophonemic processes of the nasal prefix $\{\operatorname{maN}-\}$, the suffix $\{$-hon $\}$ as well as the enclitic $=h u$. Further, types of consonant geminates resulted from affixation and clitization are intensively discussed in Section 5.

\subsection{Morphophonemics of the nasal prefix $\{\mathrm{maN}-\}$}

Capital $N$ - as used through this work represents a homorganic nasal which is found in nasal prefixes. The $N$ - of the nasal prefix $\{\mathrm{maN}-\}$ assimilates to, and sometimes substitutes for, the initial segment of the base. There are two possibilities of assimilation: (a) assimilation without substitution or (b) assimilation and substitution (=deletion of the base-initial consonant). 


\subsubsection{Assimilation without substitution}

Assimilation without substitution refers to the assimilation of the homorganic nasal of the nasal prefix without changing or substituting the first segment of the base. This process mostly involves homorganic assimilation.

The homorganic nasal $N$ - of $\{\mathrm{maN}-\}$ occurs as bilabial nasal $/ \mathrm{m} /$ when it precedes the voiced bilabial stop $/ \mathrm{b} /$. It occurs as the alveolar nasal $/ \mathrm{n} /$ when it precedes the voiced apicoalveolar stop /d/ and the voiceless apico-alveolar fricative /s/. It occurs as the alveolar nasal $/ \mathrm{n} /$ when it precedes the voiced alveolar affricate $/ \mathrm{d} 3 /$, the voiced apico-alveolar lateral $/ 1 /$ and voiced apico-alveolar trill $/ \mathrm{r} /$. It occurs as $/ \mathrm{y} /$ when it precedes the voiceless dorso-velar stop $/ \mathrm{k} /$, the voiced dorso-velar stop /g/ and the voiceless glottal fricative $/ \mathrm{h} /$. The following examples illustrate it.

(1) $\{$ maN- $\}+$ bahen 'to make' $\rightarrow$ mambahen 'to make'

(2) $\{\mathrm{maN}-\}+$ dilat 'to lick' $\rightarrow$ mandilat 'to lick'

(3) $\{$ maN- $\}+$ lulus 'to warm-up (by fire)' $\rightarrow$ manlulus 'to warm-up (by fire)'

(4) $\{\mathrm{maN}-\}+$ rohop 'to hug' $\rightarrow$ manrohop 'to hug'

(5) $\{\mathrm{maN}-\}+s a r i$ 'to earn money' $\rightarrow$ mansari 'to earn money'

(6) $\{$ maN- $\}+$ jagul 'to select' $\rightarrow$ manjagul 'to select'

(7) $\{$ maN- $\}+$ kail 'fish hook' $\rightarrow$ mangkail 'to fish'

(8) $\{$ maN- $\}+$ gaor 'to stir' $\rightarrow$ manggaor 'to stir'

(9) $\{$ maN- $\}+$ harat 'to bite' $\rightarrow$ mangharat 'to bite'

From the above examples, it can be seen that the assimilation without substitution results in nasal-obstruent sequences $/ \mathrm{mb} /, / \mathrm{nd} /, / \mathrm{ns} /, / \mathrm{nd} 3 /, / \mathrm{nl} /, / \mathrm{nr} /, / \mathrm{yk} /, / \mathrm{yg} /$ and $/ \mathrm{yh} /$. Further, these sequences may change into consonant geminates which are discussed in Section 5.1.

Before vowels the homorganic nasal $N$ - is realized as $/ \mathrm{y} /$ as illustrated by the following examples.

(10) $\{\mathrm{maN}-\}+$ ayak 'to chase' $\rightarrow$ mangayak 'to chase'

(11) $\{$ maN- $\}+\boldsymbol{u} d u t$ 'to join' $+\{$-hon $\} \rightarrow$ mangudut 'to join'

(12) $\{$ maN- $\}+$ osor 'to move' $\rightarrow$ mangosor 'to move'

(13) $\{$ maN- $\}+$ imas 'to cut off' $\rightarrow$ mangimas 'to cut off'

(14) $\{\mathrm{maN}-\}+$ ebeng 'to request' $\rightarrow$ mangebeng 'to request'

\subsubsection{Assimilation and substitution}

Assimilation and substitution is a combined process in which the homorganic nasal is assimilated to and then substitutes for the first segment of the base. This process may occur when the initial segment of the base is a voiceless stop /p/, /t/ or $/ \mathrm{k} /$ and the voiceless apicoalveolar fricative $/ \mathrm{s} /$. The homorganic nasal $N$ - of $\left\{\mathrm{maN}_{-}\right\}$changes into bilabial $/ \mathrm{m} /$ when it precedes bases begin with voiceless bilabial stop $/ \mathrm{p} /$; it occurs as apico-alveolar nasal $/ \mathrm{n} /$ when it precedes bases begin with voiceless apico-alveolar stop / $t /$ and voiceless apico-alveolar fricative $/ \mathrm{s} /$; it becomes $/ \mathrm{y} /$ when it attaches to bases begin with the voiceless dorso-velar $/ \mathrm{k} /$. Note that this process is not fully regular, as the voiceless stop $/ \mathrm{k} /$ and the voiceless apico-alveolar fricative /s/ may also undergo assimilation without substitution, as presented in Section 3.1.1. The examples can be seen below.

(15) $\{\mathrm{maN}-\}+$ pokpok 'to hit' $\rightarrow$ mamokpok 'to hit'

(16) $\{\mathrm{maN}-\}+$ tektek 'to drop' $\rightarrow$ manektek 'to drop' 
(17) $\{$ maN- $\}+$ suan 'to plant' $\rightarrow$ manuan 'to plant'

(18) $\{$ maN- $\}+$ kiskis 'to clear grass' $\rightarrow$ mangiskis 'to clear grass'

\subsection{Morphophonemics of the suffix \{-hon\}}

The causative/imperative suffix \{-hon\} in Simalungun may occur as [-hon] or [-kon] depending on the final consonant of bases to which it attaches. It becomes [-kon] when it follows bases ended with $/ \mathrm{p} /, / \mathrm{t} /, / \mathrm{k} /, / \mathrm{s} /, / \mathrm{h} /$ and $/ \mathrm{y} /$. The following examples illustrate it.

(19) $\{$ maN- $\}+$ ponop 'to hide' $+\{$-hon $\} \rightarrow$ mamonopkon 'to hide'

(20) $\{$ pa- $\}+$ sangap 'to honour' $+\{$-hon $\} \rightarrow$ pasangapkon 'to honour'

(21) solot 'to insert' $+\{$-hon $\} \rightarrow$ solotkon 'to insert.IMP'

(22) $\{$ maN- $\}+$ ramot 'to take care' $+\{$-hon $\} \rightarrow$ manramotkon 'to take care'

(23) dokdok 'to pull' $+\{$-hon $\} \rightarrow$ dokdokkon 'pull.IMP'

(24) $\{\mathrm{maN}-\}+$ pokpok 'to hit' $+\{$-hon $\} \rightarrow$ mamokpokkon 'to hit'

(25) kiskis 'to clear grass' $+\{$-hon $\} \rightarrow$ kiskishon 'clear grass.IMP'

(26) $\{\mathrm{i}-\}+$ bois 'to finish' $+\{$-hon $\} \rightarrow$ iboiskon 'to be finished'

(27) $\{$ maN- $\}+$ posah 'to break' $+\{$-hon $\} \rightarrow$ mamosahkon 'to break'

(28) $\{\mathrm{i}-\}+$ utah 'vomit' $+\{$-hon $\} \rightarrow$ iutahkon 'to be vomited'

(29) $\{$ maN- $\}+$ tading 'to leave' $+\{$-hon $\} \rightarrow$ manadingkon 'to leave'

(30) $\{\mathrm{i}-\}+$ hading 'to hang' $+\{$-hon $\} \rightarrow$ ihadingkon 'to be hanged'

The consonant sequences $\langle\mathrm{kk}\rangle$ and $\langle\mathrm{ngk}\rangle$ are further analyzed as sequences result in consonant geminate [kk] as presented in Section 5.1 and 5.3.

The suffix \{-hon\} occurs as [-hon] when it attaches to bases ended with other consonants and vowels. See the following examples.

(31) garut 'to scratch' $+\{$-hon $\} \rightarrow$ garuthon 'scratch.IMP'

(32) $\{$ pa- $\}+$ hundul 'to sit' $+\{$-hon $\} \rightarrow$ pahundulhon 'to make s.o. sit.IMP'

(33) podom 'to sleep' $+\{$-hon $\} \rightarrow$ podomhon 'to make s.o. sleep.IMP'

(34) $\{$ pa- $\}+$ gurgur 'to boil' $+\{$-hon $\} \rightarrow$ pagurgurhon 'boil.IMP'

(35) suan 'to plant' $+\{$-hon $\} \rightarrow$ suanhon 'plant.IMP'

(36) taba 'to cut' $+\{$-hon $\} \rightarrow$ tabahon 'cut.IMP'

(37) $\{$ maR- $\}+$ nipi 'to dream' $+\{$-hon $\} \rightarrow$ marnipihon 'to dream'

(38) aru 'to offer' $+\{$-hon $\} \rightarrow$ aruhon 'to offer'

\subsection{Clitization with the enclitic $=\mathrm{hu}$ and $=\mathrm{ni}$}

The morphophonemic processes change the enclitic $=h u$ '1SG.POSS' into $=k u$ or $=h u$ depending on the bases to which it attaches. It occurs as $=h u$ if it follows bases ended with $/ \mathrm{k} /$ and vowels, as presented by the examples below.

(39) $u l u$ 'head' $+=h u \rightarrow$ uluku 'my head'

(40) naboru 'woman' + =hu $\rightarrow$ naboruku 'my woman'

(41) lapo 'food stall' $+=h u \rightarrow$ lapoku 'my food stall'

(42) boltok 'stomach' $+=h u \rightarrow$ boltokku 'my stomach'

(43) anak 'child' $+=h u \rightarrow$ anakku 'my child'

From the examples (42) and (43), it can be seen that the morphophonemic process between bases and the enclitic $=h u$ results in a consonant geminate [kk]. This geminate is further discussed in Section 5.3. 
The enclitic $=h u$ maintains its form or occurs as $=h u$, when it attaches to bases ended with consonants other than $/ \mathrm{k} /$. See the examples below.

(44) untut 'fart' $+=h u \rightarrow$ untuthu 'my fart'

(45) tois 'feces' $+=h u \rightarrow$ toishu 'my feces'

(46) podom 'to sleep' $+\{-$ an $\}+=h u \rightarrow$ podomanhu 'my bed'

(47) huyum 'cheek' $+=h u \rightarrow$ huyumhu 'my cheek'

(48) goran 'name' $+=h u \rightarrow$ goranhu 'my name'

In contrast to the enclitic $=h u$ '1SG.POSS' which may change into $=h u$ or $=k u$ depending on the bases to which it attaches, the enclitic $=n i$ '3SG.POSS' undergoes no changes. It always occurs as $=n i$ as presented by the following examples.

(49) gerger 'red' $+=n i \rightarrow$ gergerni 'its redness'

(50) motor 'motorbike' $+=n i \rightarrow$ motorni 'his/her motorbike'

(51) kalas 'class' $+=n i \rightarrow$ kalasni 'his/her class'

(52) anak 'child' $+=n i \rightarrow$ anakni 'his/her child'

(53) hasoman 'friend' $+=n i \rightarrow$ hasomanni 'his/her friend'

(54) huta 'village' $+=n i \rightarrow$ hutani 'his/her village'

Example (53) shows that the nasal geminate $[\mathrm{nn}]$ is resulted from the enclitic $=n i$ which follows bases ended with $/ \mathrm{n} /$. This geminate is further discussed in Section 5.4.

\section{NASAL-OBSTRUENT SEQUENCES}

Before discussing consonant geminates in Simalungun language, it is useful to find out nasalobstruent sequences in this language. Nasal-obstruent sequences occur in this language can be divided into two types: a nasal follows by homorganic stops and a nasal follows by nonhomorganic stops. Nasal-obstruent sequences in Simalungun only occur word-medially. Sequences of nasal and homorganic stops found in Simalungun language are $/ \mathrm{mb} /, / \mathrm{mp} /, / \mathrm{nd} /$, $/ \mathrm{nt} /, / \mathrm{nd} 3 /, / \mathrm{ns} /, / \mathrm{nl} /, / \mathrm{ng} /, / \mathrm{yk} /$ and $/ \mathrm{yh} /$ as in tambing 'be swollen', salimpotpot 'firefly', hundulan 'bench', untut 'fart', ganjang 'be long', konsing 'to pee', maN-lulus > manlulus 'to warm-up (by fire)', sanggah 'progressive aspect', angkula 'body' and maN-harat > mangharat 'to bite' or gurung=hu > gurungh $u$ 'my back'.

In addition to occur morpheme-internally (lexicalized), nasal-obstruents in Simalungun may be resulted from affixation and clitization. Affixation which results in nasal-obstruent sequences with homorganic stops is the use of the nasal prefix $\{\mathrm{maN}-\}$, as in maN-lulus > manlulus 'to warm-up (by fire)' or maN-harat > mangharat 'to bite'. In case of clitization, sequences of nasal and non-homorganic stops occur when the enclitic $=h u$ ' 1 SG.POSS' follows bases or hosts ended with nasals other than $/ \mathrm{y} /$, i.e. $/ \mathrm{m} /$ and $/ \mathrm{n} /$. The sequences found are $/ \mathrm{mh} /$ and $/ \mathrm{nh} /$ as in huyum=h $u>$ huyumh $u$ 'my cheek' and poyun=h $u>$ poyonh $u$ 'my grass'. Consonant clusters other than nasal-homorganic stops like this suggest the morphological unit $=h u$ '1SG.POSS' should be analyzed as clitic, rather than morpheme (cf. Damanik et.al. (1984) who analyze this unit as suffix). Such sequences that remain phonologically unaltered may only occur between clitics and their hosts. 


\section{CONSONANT GEMINATES}

Consonant geminates in Simalungun language always occur word-medially, never word-initially or word-finally. Geminates in this paper are written both orthographically and phonetically. It is due to the fact that Simalungun speakers maintain to write consonant geminates orthographically, i.e. as nasal-obstruent sequences, but phonetically pronounce them as consonant geminates.

The discussion on consonant geminates in this language can be divided into four types: (1) consonant geminates resulted from assimilation of a nasal to a following homorganic stop, (2) consonant geminates resulted from velarization and assimilation, (3) assimilation of heterorganic consonant clusters and (4) nasal geminates. Each of the consonant geminate is analyzed as follows.

\subsection{Consonant geminates resulted from assimilation}

Following the terminology used by Blevins (2004) or Blust (2013), the first type of consonant geminates in Simalungun is resulted from assimilation of a nasal to a following homorganic stop. In this case, the resulted geminates consist of two identical stops which are homorganic to the nasal. From the nasal-obstruent sequences which potentially change into geminates as listed in Section 4, Tabel 3 presents examples of lexicalized consonant geminates whose nasals are assimilated to the following homorganic stops and result in consonant geminates. The assimilation changes $\langle\mathrm{mp}>$ sequence into [pp], $\langle\mathrm{nt}\rangle$ changes into [tt], $\langle\mathrm{ns}\rangle$ changes into [ss], $<\mathrm{ngg}>$ changes into $[\mathrm{gg}]$ and $<\mathrm{ngk}>$ changes into $[\mathrm{kk}]$.

Table 3: Lexicalized consonant geminates in Simalungun

\begin{tabular}{|l|l|l|l|}
\hline No. & Nasal-Obstruents & Consonant Geminates & Examples \\
\hline 1. & $\langle\mathrm{mp}>$ & {$[\mathrm{pp}]$} & $\begin{array}{l}\text { /sompul/ > [soppul] 'to blow' } \\
\text { /lompah/ }>\text { [loppah] 'vegetable' }\end{array}$ \\
\hline 2. & $<\mathrm{nt}>$ & {$[\mathrm{tt}]$} & $\begin{array}{l}\text { /lintun/ > [littun] 'to run' } \\
\text { /santun/ }>\text { [sattun] 'stupid' }\end{array}$ \\
\hline 3. & $<\mathrm{ns}>$ & {$[\mathrm{ss}]$} & $\begin{array}{l}\text { /konsing/ }>\text { [kossing] 'to pee' } \\
\text { /lansina/ }>\text { [lassina] 'chili' }\end{array}$ \\
\hline 4. & $<\mathrm{ngg}>$ & {$[\mathrm{gg}]$} & /banggal/ > [baggal] 'big' \\
\hline 5. & $<\mathrm{ngk}>$ & {$[\mathrm{kk}]$} & $\begin{array}{l}\text { /angkula/ > [akkula] 'body' } \\
\text { /tingki/ }>\text { [tikki] 'time' }\end{array}$ \\
\hline
\end{tabular}

In addition to occur morpheme-internally or lexicalized, as shown in Table 3, consonant geminates resulted from assimilation may be also caused by affixation, i.e. by the use of the nasal prefix $\{\mathrm{maN}-\}$. Consonant geminates resulted from affixation found in the database are [ss], [kk] and [11]. The consonant geminate [ss] is resulted from the nasal prefix $\{$ maN- $\}$ which attaches to bases begin with $/ \mathrm{s} /$. In this case, the assimilation changes the nasal-obstruent sequence $\langle\mathrm{ns}\rangle$ into [ss], as shown by example (55).

(55) $\{\mathrm{maN}-\}+$ sari 'to earn money' $\rightarrow$ <mansari $>$ /mansari/ $\rightarrow$ [massari] 'to earn money'

The consonant geminate $[\mathrm{kk}]$ is resulted from the nasal prefix $\{\mathrm{maN}-\}$ which attaches to bases begin with $/ \mathrm{k} /$. The assimilation changes the nasal-obstruent sequence $<\mathrm{ngk}>$ into [kk], as can be seen in (56) and (57).

(56) $\{$ maN- $\}+$ kail 'fish hook' $\rightarrow$ <mangkail $>$ /mankail/ $\rightarrow$ [makkail] 'to fish' 
The consonant geminate [11] is resulted from the nasal prefix $\{\mathrm{maN}-\}$ which attaches to bases begin with /1/. In this case, the assimilation changes the nasal-obstruent $<$ nl $>$ into [11], as presented by example (58) and (59).

(58) $\{$ maN- $\}+$ langkah 'to step' $\rightarrow$ <manlangkah $>$ /manlankah/ $\rightarrow$ [mallakkah] 'to step'

(59) $\{$ maN- $\}+$ lulus 'to warm-up (by fire)' $\rightarrow\langle$ manlulus $>$ /manlulus/ $\rightarrow$ [mallulus] 'to warm-up (by fire)'

From the examples, it can be seen that most geminates found in Simalungun are voiceless: [pp], [tt], [ss], and [kk]; voiced geminates found in this language are [gg] and [11]. This finding is in line with Blevins (2004:179) in which she states that the tendency for geminate oral stops to be voiceless follows the aerodynamic properties of stop production: the longer the stop closure, the more difficult it is to sustain voicing.

\subsection{Consonant geminates resulted from velarization and assimilation}

In contrast to gemination described in the Section 5.1, the gemination of the nasal-obstruent sequence $<$ ngh $>$ does not follow the assimilation of a nasal to a following homorganic stops: instead of becoming *[hh], <ngh> changes into [kk]. In this case, it may be assumed that the <ngh> sequence undergoes two phonological processes: velarization and assimilation. First, the [h] sound in $[\mathrm{nh}]$ is velarized into [ $\mathrm{nk}]$. As it is velarized into [k], the nasal [n] in [ $\mathrm{nk}]$ could be then assimilated into [kk]. Velarization in this case may be caused by the non-existence of an appropriate nasal for the glottal sound [h]. The closest nasal sound to [h] is the velar nasal [ $\mathrm{y}]$.

The gemination through velarization and assimilation, $<\mathrm{ngh}>$ into [kk], is resulted from affixation. The affixes involved in this process are the nasal prefix $\{\mathrm{maN}-\}$ and the suffix $\{$-hon $\}$. The geminate $[\mathrm{kk}]$ occurs when the nasal prefix $\{\mathrm{maN}-\}$ precedes bases begin with $/ \mathrm{h} /$ or when the suffix $\{$-hon $\}$ follows bases ended with $/ \mathrm{y} /$. Here are some examples.

(60) $\{$ maN- $\}+$ harat 'to bite' $\rightarrow$ <mangharat>/manharat/ $\rightarrow$ [mankarat] $\rightarrow$ [makkarat] 'to bite'

(61) $\{$ maN- $\}+$ hasoman 'friend' $+\{-\mathrm{i}\} \rightarrow$ <manghasomani $>$ /manhasomani/ $\rightarrow$ [mankasomani] $\rightarrow$ [makkasomani] 'to accompany'

(62) $\{$ maN- $\}+$ tading 'to leave' $+\{$-hon $\} \rightarrow$ <manadinghon $>$ /manadinhon/ $\rightarrow$ [manadinkon] $\rightarrow$ [manadikkon] 'to leave'

In addition to affixation, this type of geminate could also be found morpheme-internally or lexicalized. For example, the word <munghor> is pronounced as [mukkor] 'snore'.

\subsection{Assimilation of heterorganic consonant clusters}

The third type of gemination found in Simalungun is assimilation of heterorganic consonant clusters (see Blust 2013). Heterorganic consonant cluster assimilation in this language follows the pattern, $\mathrm{C}_{1} \mathrm{C}_{2}>\mathrm{C}_{1} \mathrm{C}_{1}$. The consonant geminate resulted from this process is [kk]. It is resulted from affixation, i.e. the suffix \{-hon $\}$ follows bases ended with $/ \mathrm{k} /$, and clitization, i.e. the enclitic $=h u$ ' 1 SG.POSS' follows bases ended with $/ \mathrm{k} /$. The following examples illustrate it.

(63) $\{$ maN- $\}+$ pokpok 'to hit' $+\{$-hon $\} \rightarrow$ <mamokpokhon $>/$ mamokpokhon/ $\rightarrow$ [mamokpokkon] 'to hit' 
(64) $\{$ maN- $\}+$ barek 'to give' $+\{$-hon $\} \rightarrow<$ mambarekhon $>/$ mambarekhon/ $\rightarrow$ [mambarekkon] 'to give'

(65) boltok 'stomach' $+=h u \rightarrow$ <boltokhu $>/$ boltokhu/ $\rightarrow$ [boltokku] 'my stomach'

(66) anak 'child' $+=h u \rightarrow$ <anakhu > /anakhu/ $\rightarrow$ [anakku] 'my child'

\subsection{Nasal geminates}

In addition to consonant geminates which are resulted from (1) assimilation of a nasal to a following homorganic stop, (2) velarization and assimilation and (3) assimilation of heterorganic consonant clusters, there are consonant geminates which consist of two identical nasals, namely $[\mathrm{mm}]$ and $[\mathrm{nn}]$.

The nasal geminate $[\mathrm{mm}]$ is found morpheme-internally or lexicalized, as in <summah> [summah] 'to kiss' and <domma> [domma] 'already'. However, the nasal geminate [nn] is only found in morpheme-boundary, i.e. when the enclitic $=n i$ '3SG.POSS' follows bases ended with the velar nasal $/ \mathrm{n} /$. Examine the word itadikkonni [itadikkonni] in (67) and goranni [goranni] in (68) below.

$\begin{array}{llll}\text { Motor } & \text { itadikkonni } & i & \text { Raya } \\ \text { Motor } & \text { i-tading-hon=ni } & i & \text { Raya } \\ \text { Motor.bike } & \text { PV-leave-CAUS=3.SG.POSS } & \text { prep } & \text { Raya } \\ \text { 'He left the motor bike in Raya.' } & & \end{array}$
(68) goranni Fitri
goran=ni Fitri
name $=3$ SG.POSS Fitri
'Her name is Fitri.'

\subsection{True and fake geminates}

Blevins (2004:169) classifies two kinds of geminates: true and fake geminates. True geminates are single long segments with single-feature bundles. Fake geminates are sequences of identical short segments. Further, she also argues that morpheme-internal geminates and geminates which arise via assimilation are true geminates (Blevins 2004:170). Meanwhile, geminates which arise via morpheme concatenation are considered as fake geminates (Blevins 2004:170).

Based on Blevin's definition, geminates in Simalungun language can also be divided into two types: true and fake geminates. Geminates which occur morpheme-internally (lexicalized) are true geminates. True geminates found in this language are [pp], [tt], [ss], [kk], [gg] and [mm]. Orthographically, [pp] is written as $\langle\mathrm{mp}\rangle$, [tt] as $\langle\mathrm{nt}\rangle$, [ss] as $\langle\mathrm{ns}\rangle$, [kk] as $<\mathrm{ngk}\rangle$ or $\langle\mathrm{ngh}\rangle$, $[\mathrm{gg}]$ as $\langle\mathrm{ngg}\rangle$ and $[\mathrm{mm}]$ as $\langle\mathrm{mm}\rangle$.

In contrast, geminates resulted from affixation or clitization or geminates arise via morpheme concatenation are defined as fake geminates. Fake geminates in Simalungun language are [ss], [kk], [1l] and [nn]. The geminate [ss] is resulted from the use of the nasal prefix $\{\mathrm{maN}-\}$ attaches to bases begin with $/ \mathrm{s} / ;[\mathrm{kk}]$ is resulted from the use of the nasal prefix $\{\mathrm{maN}-\}$ attaches to bases begin with $/ \mathrm{k} /$ or $/ \mathrm{h} /$ as well as the suffix $\{-\mathrm{hon}\}$ which follows bases ended with $/ \mathrm{y} /$ or the enclitic $=h u$ which follows bases ended with $/ \mathrm{k} /$; [11] is resulted from the use of the nasal prefix $\{\mathrm{maN}-\}$ attaches to bases begin with $/ 1 /$; $[\mathrm{nn}]$ is resulted from the use of the enclitic $=$ ni ' 3 SG.POSS' which follows bases ended with $/ \mathrm{n} /$. 


\section{CONCLUSION}

From the analysis, it can be concluded that the morphophonemic processes which result in consonant geminates in Simalungun are affixation and clitization. Affixation involves the use of the nasal prefix $\{$ maN- $\}$, the suffix $\{$-hon $\}$, the enclitic $=h u$ and the enclitic $=n i$.

Consonant geminates in Simalungun language always occur word-medially, never word-initially or word-finally. Consonant geminates found in this language are [pp], [tt], [kk], [ss], [11], [gg], [nn] and [mm].

Based on the morphophonemic processes, geminates in Simalungun language can be divided into four types: (1) consonant geminates resulted from assimilation of a nasal to a following homorganic stop, (2) consonant geminates resulted from velarization and assimilation, (3) assimilation of heterorganic consonant clusters and (4) nasal geminates.

Regarding true and fake type of geminates, true geminates in Simalungun are found morpheme-internally or lexicalized; fake geminates are resulted from affixation and clitization. True geminates in Simalungun are [pp], [tt], [ss], [kk], [gg] and [mm], while the fake geminates found in this language are [ss], [kk], [11] and [nn].

\section{List of Abbreviations:}

$\begin{array}{ll}1 & \text { first person } \\ 2 & \begin{array}{l}\text { second person } \\ \text { third person }\end{array} \\ 3 & \text { consonant } \\ \text { C } & \text { causative } \\ \text { CAUS } & \text { exclusive } \\ \text { EX } & \text { honorific } \\ \text { HON } & \text { imperative } \\ \text { IMP } & \text { nominalizer } \\ \text { NOM } & \text { preposition } \\ \text { prep } & \text { plural } \\ \text { PL } & \text { possessive } \\ \text { POSS } & \text { passive voice } \\ \text { PV } & \text { singular } \\ \text { SG } & \text { vowel } \\ \text { V } & \end{array}$

\section{NOTE}

*The author would like to thank two anonymous reviewers for their helpful comments on the earlier version of this paper.

\section{References}

Adelaar, A. 2001. Structural diversity in the Malayic subgroup. In A. Adelaar and N. P. Himmelmann (Eds.), The Austronesian Languages of Asia and Madagascar, pp. 202-226. London/New York: Routledge.

Baharuddin et.al. 1997. Limbaga (Peribahasa bahasa Simalungun). Jakarta: Pusat Pembinaan dan Pengembangan Bahasa, Departemen Pendidikan dan Kebudayaan.

Blevins, J. 2004. Evolutionary phonology: The emergence of sound patterns. Cambridge: CUP. 
Blust, R. 2013. The Austronesian languages. Canberra: Asia-Pacific Linguistics.

Bowden, J. and J. Hajek. 1999. Taba and Roma: Clusters and geminates in two Austronesian languages, Proceedings of the XIVth International Congress of Phonetic Sciences, pp. 1033-1036.

Damanik, U. H. et.al. 1984. Morfologi dan sintaksis bahasa Batak Simalungun. Jakarta: Pusat Pembinaan dan Pengembangan Bahasa, Departemen Pendidikan dan Kebudayaan.

Himmelmann, N. P. 2001. Sourcebook on Tomini-Tolitoli languages. Canberra: Pacific Linguistics.

Lewis, M. P, Gary F. S., and Charles D. Fennig (eds.). 2016. Ethnologue: Languages of the world, 19th edition. Dallas, Texas: SIL International.

Mayani, L. A. 2013. A Grammar of Tajio, A language spoken in Central Sulawesi. Doctoral Dissertation: University of Cologne.

Nastiti L. D. 2014. Kontak bahasa antara komunitas tutur bahasa Bugis dan komunitas tutur bahasa Samawa di Sumbawa. In Medan Bahasa, Vol.8/No.2, pp. 194-220. Sidoarjo: Balai Bahasa Provinsi Jawa Timur.

Siregar, B. U. et.al. 2001. Fonologi bahasa Simalungun. Jakarta: Pusat Pembinaan dan Pengembangan Bahasa, Departemen Pendidikan dan Kebudayaan.

Sitanggang, S.R.H. 1996. Zimbo (Cerita rakyat Simalungun). Jakarta: Pusat Pembinaan dan Pengembangan Bahasa, Departemen Pendidikan dan Kebudayaan.

Tarigan, H.G. 1975. Morfologi bahasa Simalungun. Doctoral Dissertation: University of Indonesia. 